\title{
ECTOPIC LACRIMAL GLANDULAR TISSUE WITHIN THE EYEBALL*
}

\author{
BY \\ RUSSELL DALLACHY \\ From the Clinical Laboratories, Victoria Infirmary of Glasgow
}

ALTHOUGH there are many small accessory lacrimal glands present in upper and lower eyelids, it is very uncommon for them to undergo adenomatous hyperplasia, and it is extremely rare for lacrimal glandular tissue to be found on or in the eyeball. An example of the second type of malformation is recorded in the present paper. It is the third case in which apparently normal lacrimal glandular tissue has formed a relatively large mass in the substance of the iris and ciliary body. Seven cases in which similar tissue occurred deep to the conjunctiva are also reviewed briefly.

\section{Case Report}

A female infant was first seen at the age of 2 months. The parents had noticed that the left eye had been abnormal since birth.

Examination.-A pink, nodular, fleshy tumour was present in the anterior chamber of the left eye and occupied most of the upper nasal quadrant. It appeared to arise from the ciliary body. The appearance of the left optic fundus was normal. There was no increase in the size of the tumour over the ensuing 6 months. Diagnoses considered were leiomyoma of iris, neurofibroma, and diktyoma (medullo-epithelioma), but no firm conclusion was reached before operation. The appearances of the tumour just before it was excised are shown in Fig. 1.

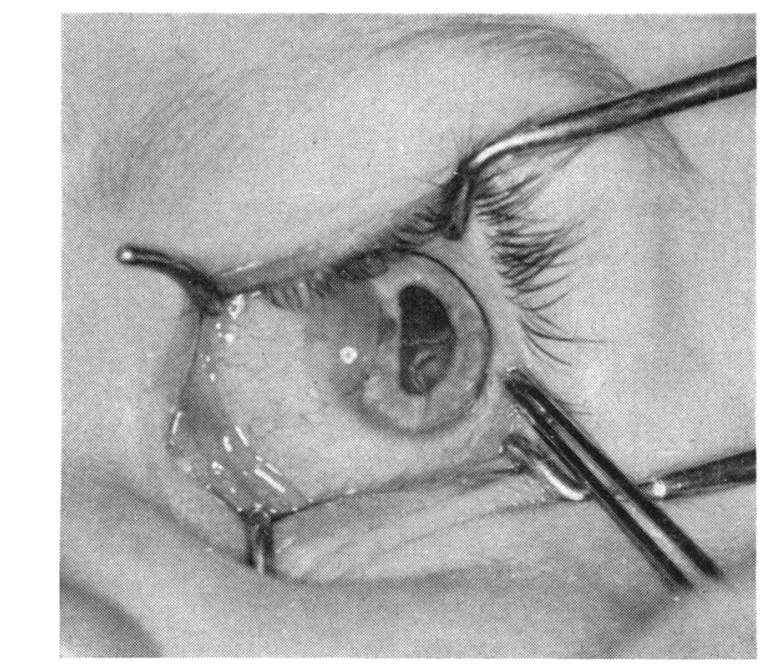

Fig. 1.-Clinical appearance of left eye immediately before local removal of lesion of iris and ciliary body.

* Received for publication February 9, 1961 
Operation.-A conservative operation was performed, the tumour being removed locally with the adjacent portion of iris. The immediate post-operative result was satisfactory, but the eyeball began to shrink and enucleation was performed one month later. An artificial eye was fitted, and the socket was healthy 4 years later.

Progress.-About 18 months after the eye had been enucleated, the patient was admitted to the Royal Hospital for Sick Children, Glasgow, because of vague ill health. Tonsillectomy was performed, and while in hospital, she was found to have a patent ductus arteriosus, with a loud systolic murmur at the left sternal border, but no enlargement of the heart; the brachial blood pressure was $105 / 50 \mathrm{~mm}$. Hg. The patient was transferred to Mearnskirk Hospital, where the patent ductus arteriosus was ligated; $\mathbf{3}$ years later, at the age of 5 years, the child was in good general health.

Pathology.-The tumour was a soft pinkish mass, which was faintly translucent. It was quite firm and measured $8 \times 6 \times 4 \mathrm{~mm}$. The posterior surface was covered by iris which was thin over the mid-zone of the tumour. The cut surface was smooth and was pale grey with a few dark grey dots.

The microscopic appearances were those of ectopic lacrimal glandular tissue situated in the ciliary body and iris. The structure of this tissue was similar to that of the mature lacrimal gland (Fig. 2, and Fig; 3 and 4, overleaf), consisting mostly of hollow acini with relatively few ducts.

The acini, which varied slightly in size, had small central lumina. Each acinus was composed of a single layer of cuboidal or columnar epithelial cells which had welldefined cell membranes, finely granular acidophil cytoplasm, and rounded, coarsely granular nuclei at the base of the cells; the free borders of the cells had no cilia. The ducts were of moderate size and were lined by a single layer of epithelial cells which were lower

(a)

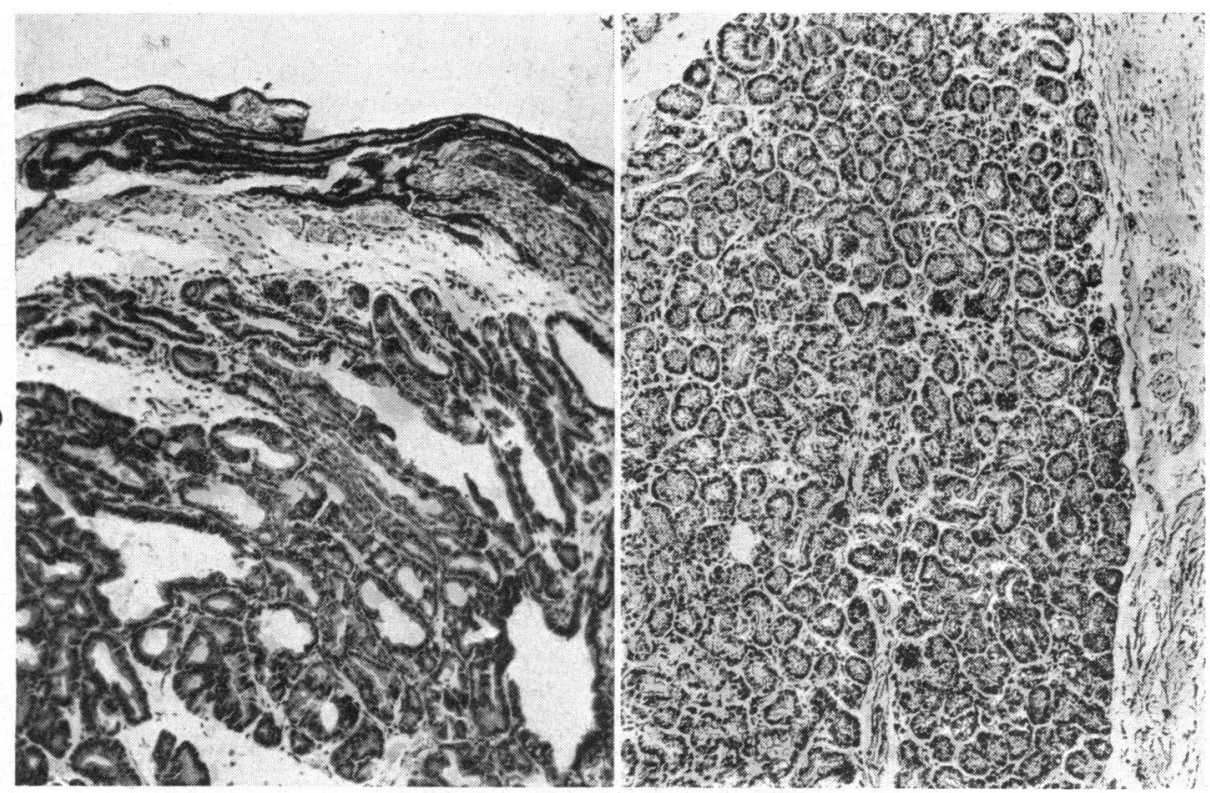

Fig. 2(a).-Ectopic lacrimal glandular tissue situated immediately deep to the posterior surface of the iris (from patient): the pigment epithelium on the posterior surface of the iris runs transversely at the top of the photomicrograph. Haematoxylin and eosin. $\times 82 \cdot 5$.

Fig. 2(b).-Section of normal lacrimal gland for comparison with Fig. $2 a$. Haematoxylin and eosin. $\times 82 \cdot 5$. 
(a)
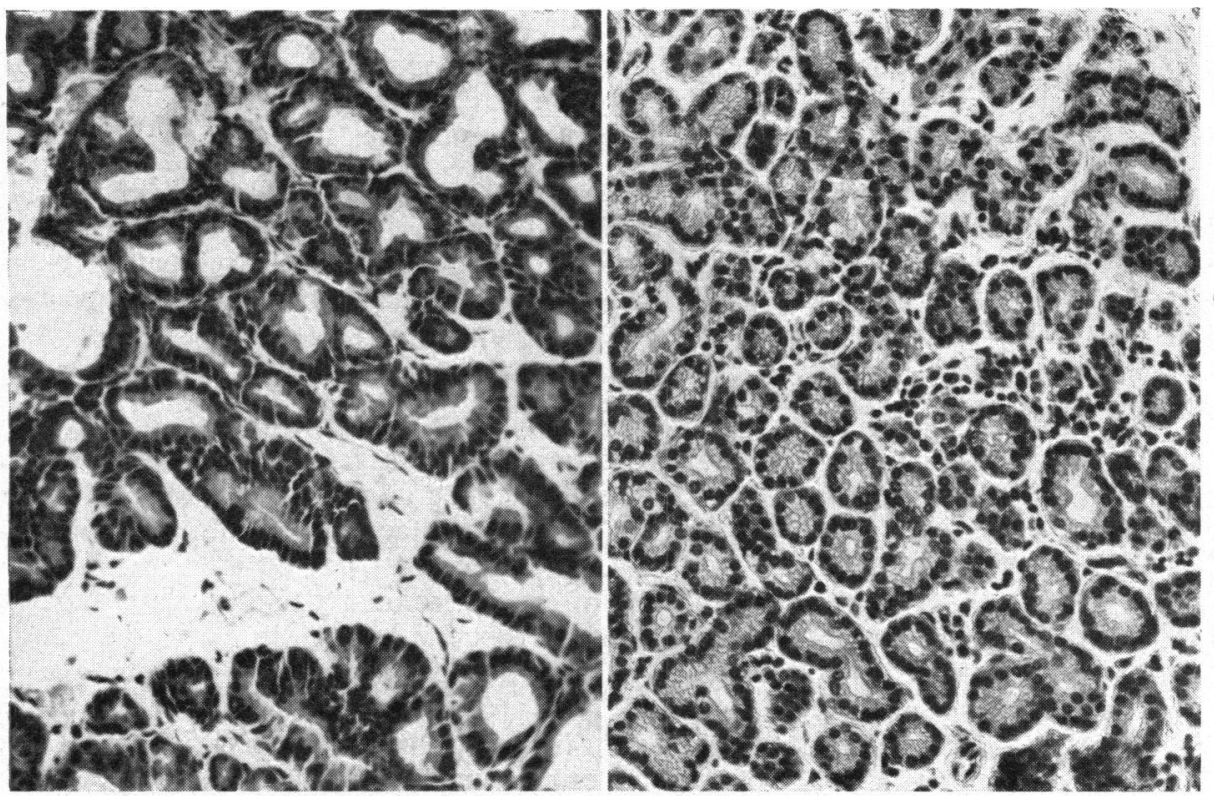

FIG. 3(a).-Ectopic lacrimal glandular tissue from iris of patient, showing numerous acini which vary in size, are often irregular in outline, and have very little interstitial fibrous tissue. Haematoxylin and eosin. $\times 188$.

Fig. 3(b).-Section of normal lacrimal gland for comparison with Fig. 3a. Haematoxylin and eosin. $\times 188$.

than those of the acini. There was very little fibrous tissue between the acini and fat spaces were absent. There was no mucin secretion demonstrable by Southgate's mucicarmine stain. Treatment of sections by the periodic acid-Schiff technique revealed droplets of Schiff-positive material within many of the cells lining the acini and lying free in large pools in the ducts (Fig. 4, opposite).

\section{Discussion}

Frequency of Occurrence of Ectopic Lacrimal Glandular Tissue.-This tissue occurs rarely; the examples reported in the literature are listed in Table I, and it can be seen that each author has encountered only one case.

TABLE I

\section{CASES OF ECTOPIC LACRIMAL GLANDULAR TISSUE IN VARIOUS SITES IN THE EYEBALL}

\begin{tabular}{|c|c|c|c|}
\hline Site of Ectopic Lacrimal Glandular Tissue & No. of Cases & Authors & Date \\
\hline $\begin{array}{l}\text { On external surface of globe between } \\
\text { bulbar conjunctiva and sclera }\end{array}$ & $\left.\begin{array}{l}4 \\
1\end{array}\right\} 5$ & $\begin{array}{l}\text { François and Rabaey (one } \\
\text { case seen; three others cited) } \\
\text { Boase }\end{array}$ & $\begin{array}{l}1951 \\
1954\end{array}$ \\
\hline $\begin{array}{l}\text { On external surface of globe between } \\
\text { bulbar conjunctiva and sclera, but ex- } \\
\text { tending on to cornea }\end{array}$ & $1\} 2$ & $\begin{array}{l}\text { Dame } \\
\text { Hughes and Ballen }\end{array}$ & $\begin{array}{l}1946 \\
1956\end{array}$ \\
\hline In iris and/or ciliary body & $\left.\begin{array}{l}1 \\
1 \\
1\end{array}\right\} 3$ & $\begin{array}{l}\text { Bruce } \\
\text { Christensen and Anderson } \\
\text { Present paper }\end{array}$ & $\begin{array}{l}1952 \\
1952 \\
1961\end{array}$ \\
\hline Total & 10 & & \\
\hline
\end{tabular}


ECTOPIC LACRIMAL・GLANDULAR TISSUE



Fig. 4(a).-Ectopic lacrimal glandular tissue from iris of patient, showing Schiff-positive (reddish-purple) material in the cytoplasm of the acinar epithelial cells towards the free borders and lying free within some of the acini. Periodic acid-Schiff. Ektachrome. $\times 220$.

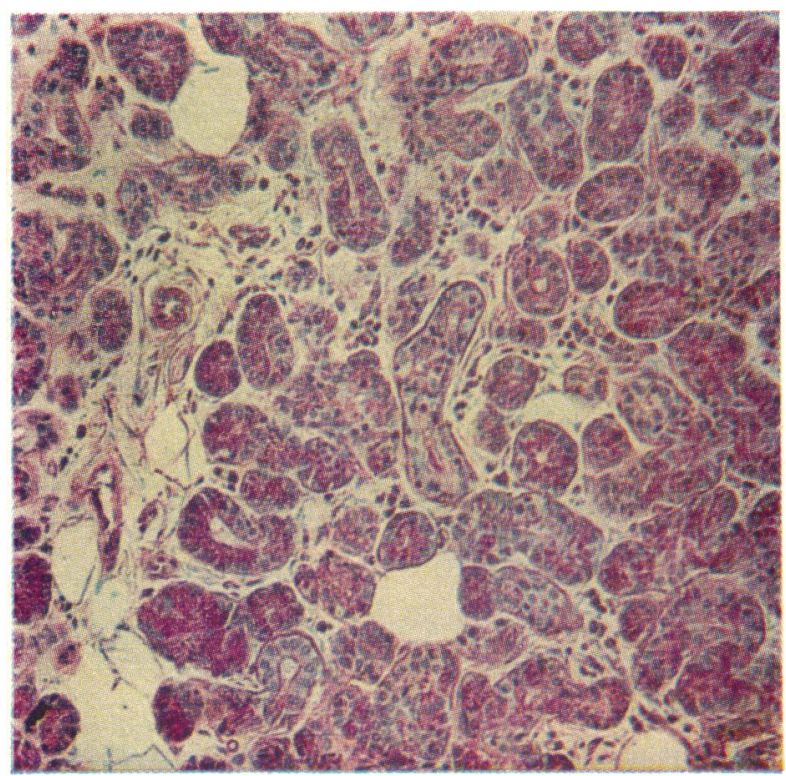

Fig. 4(b). - Section of normal lacrimal gland for comparison with Fig. $4 a$. Periodic acid-Schiff. Ektachrome. $\times 220$. 
In five patients, the lacrimal glandular tissue lay between the conjunctiva. and the sclera, and in two others it extended forwards in the same tissue plane on to the cornea. In these seven patients, the lesion was first noticed at birth in one and in late childhood in another; operative removal was not undertaken until several years later (Table II).

TABLE II

CASES OF ECTOPIC LACRIMAL GLANDULAR TISSUE OCCURRING DEEP TO THE CONJUNCTIVA, BUT NOT INVOLVING THE UVEAL TRACT

\begin{tabular}{|c|c|c|c|c|c|c|c|c|}
\hline \multicolumn{2}{|c|}{ Site } & \multicolumn{5}{|c|}{ Not Encroaching on Cornea } & \multicolumn{2}{|c|}{ Encroaching on Cornea } \\
\hline \multicolumn{2}{|c|}{ Authors } & Schirmer & Duclos & Drak & $\begin{array}{l}\text { François } \\
\text { and } \\
\text { Rabaey }\end{array}$ & Boase & Dame & $\begin{array}{l}\text { Hughes } \\
\text { and } \\
\text { Ballen }\end{array}$ \\
\hline \multicolumn{2}{|c|}{ Date } & 1891 & 1921 & 1925 & 1951 & 1954 & 1946 & 1956 \\
\hline \multirow{7}{*}{ 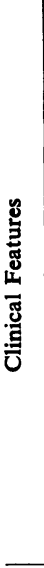 } & Sex & Male & - & 一 & Female & $\begin{array}{c}\text { Female } \\
\text { (Negro) }\end{array}$ & $\begin{array}{l}\text { Male } \\
\text { (Negro) }\end{array}$ & Female \\
\hline & $\begin{array}{l}\text { Age when } \\
\text { abnormality first } \\
\text { noted (yrs) }\end{array}$ & $\begin{array}{l}\text { Not } \\
\text { stated }\end{array}$ & 一 & - & 36 & $\begin{array}{l}\text { Lesion } \\
\text { present } \\
\text { many yrs }\end{array}$ & 13 & At Birth \\
\hline & $\begin{array}{l}\text { Age when first seen } \\
\text { by ophthalmologist } \\
\text { (yrs) }\end{array}$ & 25 & - & - & 36 & 30 & 28 & 23 \\
\hline & $\begin{array}{l}\text { Age at operation } \\
\text { (yrs) }\end{array}$ & 25 & 一 & 一 & 36 & 30 & 28 & 23 \\
\hline & Eye affected & Left & - & 一 & Right & Right & Right & Right \\
\hline & Site of lesion & $\begin{array}{l}\text { Between } \\
\text { insertion } \\
\text { of medial } \\
\text { rectus } \\
\text { muscle } \\
\text { and plica } \\
\text { semi- } \\
\text { lunaris } \\
\end{array}$ & $\begin{array}{l}\text { Near, plica } \\
\text { semi- } \\
\text { lunaris }\end{array}$ & $\begin{array}{l}\text { Near } \\
\text { limbus } \\
\text { between } \\
\text { lateral } \\
\text { and } \\
\text { superior } \\
\text { rectus } \\
\text { muscles } \\
\end{array}$ & $\begin{array}{l}\text { Limbal } \\
\text { conjunc- } \\
\text { tiva, } \\
\text { infero- } \\
\text { medial } \\
\text { quadrant }\end{array}$ & $\begin{array}{l}\text { Between } \\
\text { plica and } \\
\text { limbus }\end{array}$ & $\begin{array}{l}\text { One lesion } \\
\text { in inferior } \\
\text { temporal } \\
\text { quadrant }\end{array}$ & $\begin{array}{l}\text { Two lesions } \\
\text { in superior } \\
\text { and } \\
\text { inferior } \\
\text { quad- } \\
\text { rants }\end{array}$ \\
\hline & Size (mm.) & $3 \times 2.5 \times 2$ & & & $5 \times 3.5$ & & & \\
\hline \multicolumn{2}{|c|}{ Operation } & $\begin{array}{c}\text { Local } \\
\text { removal }\end{array}$ & - & - & \begin{tabular}{|l} 
Local \\
removal
\end{tabular} & $\begin{array}{c}\text { Local } \\
\text { removal }\end{array}$ & $\begin{array}{l}\text { Local } \\
\text { removal }\end{array}$ & $\begin{array}{l}\text { Local } \\
\text { removal }\end{array}$ \\
\hline \multicolumn{2}{|c|}{ Result of Follow-up } & $\begin{array}{l}\text { No follow- } \\
\text { up }\end{array}$ & 一 & - & $\begin{array}{l}\text { Satis- } \\
\text { factory }\end{array}$ & $\begin{array}{l}\text { No follow- } \\
\text { up }\end{array}$ & $\begin{array}{l}\text { Satis- } \\
\text { factory }\end{array}$ & $\begin{array}{l}\text { Satis- } \\
\text { factory }\end{array}$ \\
\hline
\end{tabular}

In the three patients in whom the lesion occurred in the iris and ciliary body, the affected eye was noted to be abnormal at birth or shortly afterwards, and operation was performed soon after discovery; the oldest patient at the time of excision was 6 months (Table III, overleaf).

Nomenclature of Lesion.-It is more accurate to call two of the intra-ocular lesions "collections of ectopic lacrimal glandular tissue", because they were present at birth and did not enlarge significantly during the period of observation before operation (Bruce, 1952; and the present case). The patient described by Bruce (1952) was aged 2 months when first seen, local removal of the mass was effected 5 days later, and no increase in size was noted during that period. The case described in the present paper was observed for 6 months before operation, and no increase in the size of the intra-ocular mass was seen during this period. The diagnosis of "intra-ocular adenoma" 
TABLE III

CASES IN WHICH ECTOPIC LACRIMAL GLANDULAR TISSUE OCCURRED IN THE ANTERIOR PORTION OF THE UVEAL TRACT

\begin{tabular}{|c|c|c|c|c|}
\hline \multicolumn{2}{|c|}{ Authors } & Bruce & $\begin{array}{l}\text { Christensen and } \\
\text { Anderson }\end{array}$ & Present Case \\
\hline \multicolumn{2}{|c|}{ Date } & 1952 & 1952 & 1961 \\
\hline \multirow{4}{*}{ 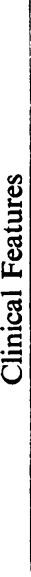 } & Sex & Male & Not stated & Female \\
\hline & $\begin{array}{l}\text { Age when } \\
\text { abnormality first } \\
\text { noted }\end{array}$ & At birth & Not stated & At birth \\
\hline & $\begin{array}{c}\text { Age when first seen by } \\
\text { ophthalmologist }\end{array}$ & $2 \mathrm{mths}$ & 2 wks & 2 mths \\
\hline & Physical findings & $\begin{array}{l}\text { Left eye: pinkish- } \\
\text { white tumour in } \\
\text { iris in lower nasal } \\
\text { quadrant; } 2 \text { mm. } \\
\text { normal iris inter- } \\
\text { vened between } \\
\text { temporal border of } \\
\text { tumour and pupil; } \\
\text { cystic area at upper } \\
\text { and lower pole of } \\
\text { tumour }\end{array}$ & $\begin{array}{l}\text { Left eye: temporal } \\
\text { half of anterior } \\
\text { chamber filled by } \\
\text { semi-transparent } \\
\text { cyst with small } \\
\text { pinkish, globular, } \\
\text { vascular body at } \\
\text { centre of lateral } \\
\text { border; attached to } \\
\text { ciliary body }\end{array}$ & $\begin{array}{l}\text { Left eye: pink, } \\
\text { nodular, fleshy } \\
\text { tumour in superior } \\
\text { nasal quadrant of } \\
\text { anterior chamber, } \\
\text { arising from ciliary } \\
\text { body. No increase } \\
\text { in size over ensu- } \\
\text { ing } 6 \text { months }\end{array}$ \\
\hline \multicolumn{2}{|c|}{ Diagnosis } & $\begin{array}{l}\text { No firm diagnosis } \\
\text { Haemangioma, } \\
\text { neurofibroma, and } \\
\text { diktyoma con- } \\
\text { sidered }\end{array}$ & $\begin{array}{l}\text { Diktyoma (medullo- } \\
\text { epithelioma) }\end{array}$ & $\begin{array}{l}\text { Leiomyoma or } \\
\text { diktyoma }\end{array}$ \\
\hline \multicolumn{2}{|c|}{$\begin{array}{l}\text { Interval between First } \\
\text { Visit and Treatment }\end{array}$} & 5 days & 4 days & $6 \mathrm{mths}$ \\
\hline \multicolumn{2}{|c|}{ Operation } & Local removal & Enucleation & Local removal \\
\hline \multicolumn{2}{|c|}{ Pathological Findings } & $\begin{array}{l}\text { Ectopic normal } \\
\text { lacrimal glandular } \\
\text { tissue in iris }\end{array}$ & $\begin{array}{l}\text { Ectopic normal } \\
\text { lacrimal glandular } \\
\text { tissue in iris, ciliary } \\
\text { body, and overlying } \\
\text { sclera and con- } \\
\text { junctiva; with } \\
\text { dehiscence at junc- } \\
\text { tion of cornea and } \\
\text { sclera through } \\
\text { which epithelium } \\
\text { grows to line a cyst } \\
\text { in the anterior } \\
\text { chamber }\end{array}$ & $\begin{array}{l}\text { Ectopic lacrimal } \\
\text { glandular tissue in } \\
\text { iris and ciliary body }\end{array}$ \\
\hline \multicolumn{2}{|c|}{$\begin{array}{l}\text { Post-operative Treat- } \\
\text { ment and Progress }\end{array}$} & $\begin{array}{l}\text { After } 6 \text { months, eye } \\
\text { healthy with no } \\
\text { recurrence }\end{array}$ & None given & $\begin{array}{l}\text { Eye began to shrink } \\
\text { several days after } \\
\text { operation } \\
\text { Enucleation } \\
\text { performed } 1 \text { month } \\
\text { later } \\
\text { No recurrence of } \\
\text { tumour after } 5 \text { years }\end{array}$ \\
\hline
\end{tabular}


in the patient reported by Christensen and Anderson (1952) seems justified. The abnormality, which was noted at birth, was first seen by these authors when the infant was 2 weeks old, and enlargement was obvious in the ensuing 5 days before enucleation of the eye was performed. The increase in size was probably due to cellular proliferation; it might have been caused by the accumulation of secretion, but this latter supposition is unlikely since numerous lacrimal ducts communicated directly with the subconjunctival space.

Evidence that the Tissue in the Iris is Ectopic Lacrimal Gland.-The histological structure of the "tumour" in the iris and ciliary body described in this paper is identical to that of the normal, mature lacrimal gland, a tubulo-alveolar exocrine gland which secretes a watery serous fluid; the microscopic structure and the secretion of the lacrimal gland closely resemble those of the parotid gland. Microscopically, the lacrimal gland consists of numerous alveoli lined by columnar or pyramidal cells resting on a basement membrane. The cells contain ovoid nuclei situated towards the base of the cells. In sections stained by haematoxylin and eosin, the cytoplasm of the resting cell is acidophil and contains numerous, small, clear vacuoles, which disappear when the cell secretes actively. These vacuoles (or, at least, some of them) contain Schiff-positive material (Fig. 4b) this material is also seen in the alveoli and in the excretory ducts. The excretory ducts are usually distinctly larger than the alveoli, and are lined by fairly tall columnar epithelium. The normal lacrimal gland contains a moderate amount of interstitial fibrous tissue and adipose tissue between the alveoli.

None of the examples of ectopic intra-ocular lacrimal glandular tissue contains significant amounts of interstitial fibro-fatty tissue, but the general microscopic structure is identical with that of the normal gland. The size and distribution of the Schiff-positive material inside and outside the cells, which is demonstrated for the first time in this paper, is comparable with that in the normal gland. In the ectopic tissue, this material is present mainly towards the free borders of the cells and is seen as fairly large pools within the excretory ducts (Fig. 4a). This is probably due to the fact that there is no free outlet for the secretion. The control lacrimal gland and the tissue from Case 1 were also stained by Southgate's mucicarmine method. No mucin was demonstrable in the lesion from the iris, and only a few minute droplets were seen in the control tissue.

Embryological Considerations.-The timetable of development in the following paragraphs is taken mainly from Hamilton, Boyd, and Mossman (1945): when the embryo is at the 5-mm. stage (35th day), the optic vesicle, which is continuous with the prosencephalon (derived from neural ectoderm), becomes invaginated distally to form the optic cup. At the same time, the ectoderm overlying the cup becomes thickened to form the lens placode; this sinks beneath the surface to become the lens vesicle at the 8-mm. stage (38th day). Mesenchyme which extends forwards into the space between the lens and the surface ectoderm gives rise to the cornea, sclera, and choroid. The iris and ciliary body are derived partly from this mesenchyme and partly from the adjacent neuroderm. At the 
same time as the lens vesicle starts to form, the cavity of the optic vesicle, which was continuous with that of the prosencephalon, becomes constricted to form the optic stalk (subsequently the optic nerve). The optic cup is incomplete inferiorly at the foetal (choroidal) fissure, which gradually becomes narrowed by the growth of its margins round the blood vessels (central artery and vein of retina). Fusion of these margins starts at the $11-\mathrm{mm}$. stage (41st day) in the intermediate portion and extends proximally and distally, so that closure of the fissure is complete at the $15-\mathrm{mm}$. stage (45th day), and subsequent development of the iris, ciliary body, and choroid takes place when the uveal tract is completely enclosed within the eyeball.

The eyelids appear as ectodermal folds at the $17-\mathrm{mm}$. stage (47th day). The lacrimal gland arises as a number of small solid epithelial buds from the conjunctival surface of the outer part of the upper lid. These epithelial buds are first noted at the $25-\mathrm{mm}$. stage (55th day), but do not become differentiated into an actively functioning tubulo-alveolar gland with six to twelve excretory ducts until the fifth or sixth lunar month.

Accessory lacrimal glands (of Krause) develop from the basal cells of the palpebral conjunctiva simultaneously with the main lacrimal gland; at birth, there are twenty to forty of these glands in the upper conjunctival fornix and six to eight in the lower. Other accessory lacrimal glands (of Wolfring-Ciaccio) are larger than those of Krause and are situated in the upper eyelid between the extremities of the tarsal sebaceous glands (François and Rabaey, 1951). Although these accessory lacrimal glands are fairly numerous, especially in the upper lid, hyperplasia or neoplasia is uncommon. The presence of lacrimal glandular tissue in or deep to the bulbar conjunctiva or cornea is even more uncommon, and as shown in Table I, only seven cases have been recorded. Similar tissue within the eyeball is extremely rare, and it is not understood how it can reach the iris and ciliary body. The period of rapid growth and differentiation in the embryo occurs between the 21st and 56th days. The choroidal (foetal) fissure normally closes during the third quarter of this period, about the 45th day, when the embryo is $15 \mathrm{~mm}$. long.

The first sign of a developing lacrimal gland is not seen until the end of the last quarter of the period, about the 55th day, when the embryo is $25 \mathrm{~mm}$. long. Furthermore, there is a zone of mesenchyme interposed between the ectoderm and structures derived from it and the iris; cornea, sclera, and choroid develop from this mesenchyme. Lastly, the lacrimal gland is situated in the superior temporal quadrant of the orbit, while the choroidal (foetal) fissure is directed infero-medially, i.e. on the diametrically opposite pole of the orbit; on anatomical grounds, a portion of lacrimal tissue, which was constricted and cut off by the closure of the fissure, as suggested by Bruce (1952), would presumably be found in the inferior nasal quadrant of the globe. In Bruce's case the lesion was, in fact, in the inferior nasal quadrant, and in . our case it was in the upper nasal quadrant; the patient described by Christensen and Anderson (1952) had an extensive and complicated associated congenital defect.

Results of Treatment.- In one case in which local removal was possible, no recurrence was reported after 6 months (Bruce, 1952). In the other (reported here), infection and shrinkage of the globe occurred after operation, and enucleation was necessary; there was no recurrence 5 years later. The patient described by Christensen and Anderson (1952) had a large complicated ocular defect when first seen, the tumour of the iris enlarged noticeably during the 
ensuing 4 days, and enucleation was therefore carried out as the primary, definitive, operative procedure; the post-operative progress is not given.

Coincident Congenital Anomalies.-The present case is the only one in which another congenital defect-patent ductus arteriosus-was found. This is the commonest congenital cardiac abnormality, and its occurrence in a patient who had the rare anomaly of congenital ectopic lacrimal tissue in the iris is probably fortuitous.

\section{Summary}

An infant who was born with a localized collection of lacrimal glandular tissue in the iris is described. This was removed locally when the patient was aged 8 months; owing to shrinkage of the globe, however, the eye was enucleated 4 weeks later. The patient was well 5 years later.

The lesion consisted of apparently normal lacrimal glandular tissue, and showed evidence of secretory function. It differed from the normal gland in two respects:

(i) There was very little interacinar fibrous tissue;

(ii) There were no fat cells.

This is only the third recorded case of ectopic lacrimal glandular tissue occurring in the anterior portion of the uveal tract; there are five cases reported in which similar tissue was found on the surface of the globe between the bulbar conjunctiva and the sclera, and in another two cases the ectopic tissue extended on to the cornea.

The iris and ciliary body complete their development within the globe after the optic cup and foetal (choroidal) fissure have closed about the 45th day of intra-uterine life. The first stages in development of the lacrimal gland are not seen until about the 55th day, and active function is delayed until the 5 th or 6 th lunar month. Study of the present case and of the other two reports has not explained how lacrimal glandular tissue reached the uveal tract.

I am indebted to Dr. Robert Leishman, Consultant Ophthalmic Surgeon to the Victoria Infirmary of Glasgow, for access to clinical records and for permission to publish. I am grateful to Dr. W. B. Davis for much helpful advice and criticism and to Mr. H. C. Gray, A.R.P.S., for assistance with the photography.

\section{REFERENCES}

BOASE, A. J. (1954). Brit. J. Ophthal., 38, 380.

BruCE, G. M. (1952). Trans. Amer. Acad. Ophthal. Otolaryng., $56,47$.

Christensen, L., and Anderson, E. D. (1952). A.M.A. Arch. Ophthal., 48, 19.

DAMe, L. R. (1946). Amer. J. Ophthal., 29, 579.

DraK, J. (1925). Klin. oczna, 3, 97 (Cited by François and Rabaey, 1951).

Duclos, L. (1921). Bull Ass. franc. Cancer, 10, 225 (Cited by François and Rabaey, 1951).

FrançoIs, J., and RABAEY, M. (1951). Brit. J. Ophthal., 35, 237.

Hamiton, W. J., Boyd, J. D., and Mossman, H. W. (1945). "Human Embryology". Heffer, Cambridge.

Hughes, W. L., and Ballen, P. H. (1956). A.M.A. Arch. Ophthal., 55, 271.

SCHIRMER, O. (1891). v. Graefes Arch. Ophthal., 37, pt. 1, p. 216. 